\title{
ПРАВОСОЗНАНИЕ ЛИЧНОСТИ И ВОСПРИЯТИЕ ЦЕННОСТЕЙ ПРАВА КАК ГАРАНТИЯ КАЧЕСТВА ПРАВОСУДИЯ
}

\author{
(c) 2020 Працко Г.С. \\ профессор кафедры гражданского и арбитражного процесса \\ Самарский государственный экономический университет, Россия, Самара \\ профессор кафедры «Коммерческое и предпринимательское право» \\ Донской государственный технический университет, Россия, Ростов-на-Дону \\ доктор философских наук, доктор юридических наук, профессор
}

В статье делается попытка с современных позиций осмыслить, обобщить, оценить и сделать некоторые теоретические и практические выводы относительно восприятия личностью ценностей права на базе своего уровня правосознания. Проводится соотношение позитивного и деформированного правосознания. Делаются выводы относительно развития правосознания членов общества как важной основы восприятия ими ценностей права.

Ключевые слова: система права, правосознание, позитивное правосознание, деформированное правосознание, функции правосознания, права и свободы личности, жизнедеятельность личности, правовое поведение.

Становление, функционирование и развитие гражданского общества и правового государства самым непосредственным образом связаны с правом, системой действующего законодательства. Поэтому практическое значение приобретают вопросы, в какой степени ценности права трансформируются в систему права, воздействуют на процессы упорядочения сущностных общественных отношений, что противодействует внедрению этих ценностей в правовую действительность. Особую значимость это приобретает в процессе отправления правосудия.

Социальная и правовая жизнедеятельность личности постоянно соприкасается с действием тех или иных законов или подзаконных нормативных актов, в которых необходимо усматривать как их сильные, полезные, так и слабые, бесперспективные стороны. Тем самым личности вслепую, подспудно или на базе обретенных юридических навыков приходится обнаруживать наличие или отсутствие тех ценностей, которые способно привносить в регулируемые общественные отношения действующее законодательство. Со знанием дела и более целенаправленно освоение ценностей права происходит у тех индивидов, субъектов права, которые являются носителями достаточно высокого уровня правового сознания и зрелой правовой культуры, прошли школу правового воспитания.

Поскольку члены общества являются массовыми субъектами правовых отношений, то выявление содержания и уровня их правосознания и правовой культуры приобретает весомое практическое значение. Такое состояние является принципиальным в условиях функционирования гражданского общества и развития правовой государственности, институты которых рассматривают человека, его права и свободы в качестве непреходящей социальной ценности.

Осваивая политическую, экономическую, социальную, духовно-культурную, правовую действительность, члены общества познают и оценивают все те грани, принципы, правила окружающего их мира людей, которые позитивно или негативно влияют на их жизненное существование, ставят каждую личность перед необходимостью выбора тех или иных форм поведения, действия, преодоления всякого рода преград, барьеров. В итоге человек нередко должен выбирать и соответствующие юридические инструменты, способные разрешить конкретные жизненные обстоятельства, то есть, призван контактировать с правом, системой действующего законодательства, конкретными нормативно-правовыми актами и юридическими нормами.

Анализ конкретных правовых жизненных обстоятельств ведет конкретного субъекта права к осмыслению тех правовых средств, которые направлены на эффективное, справедливое, приемлемое разрешение возникающих юридических дел. Параллельно выявляются и те пра- 
вовые аспекты, которые тем или способом тормозят, искажают, уводят от истины разрешение конкретных жизненных ситуаций, подрывают основы уважительного отношения членов общества к праву в целом и системе действующего законодательства, в частности.

Сказанное означает, что личность как субъект права прямо или опосредованно, но проводит грань между истинными ценностями права и теми правовыми акциями, которые противостоят личности в процессе достижения ею определенных жизненных интересов и потребностей.

Успешное выявление истинных ценностей права и их практическое освоение в решающей мере обусловлено наличием или отсутствием у конкретной личности должного уровня правосознания, правовой культуры, юридического опыта, навыков правового воспитания. Только при приобретении этих позитивно-ценностных качеств личность как субъект права приобретает способность умело распознавать правовые ценности и их полную противоположность.

Оценивая и осмысливая с названных позиций правовую действительность, личность расширяет свой правовой кругозор и тем самым усиливает потенциал правовых знаний, правосознания, правовой культуры, юридического опыта, что позволяет ей более активно и целенаправленно действовать в многогранном правовом пространстве с целью достижения своих жизненных приоритетов.

С точки зрения названных правовых перспектив и преимуществ первостепенное значение имеет правовое сознание личности как участника регулируемых правом многочисленных общественных отношений. Правовые идеи, правовые принципы, система права, правовые нормы, механизмы применения юридических норм, правосудие и многие другие правовые факторы оказывают мощное воздействие на сознание и психологию человека, находят там отражение и закрепление и тем самым вручают их носителю своеобразный ключ, позволяющий открывать доступ к разгадке и разрешению многих жизненных юридических обстоятельств.

Сознание человека как особое состояние его внутреннего мира, сформировавшееся на базе общественно-исторического развития человечества и на основе разнообразных форм человеческой деятельности, представляет собой своеобразный мыслительный сгусток психического и психологического свойства. Он дает человеку возможность обнаруживать, фиксировать, оценивать, принимать к сведению, выявлять практические свойства всех тех событий, факторов, обстоятельств, закономерностей, перипетий общественной и индивидуальной жизнедеятельности людей, наблюдателем, созерцателем и участником которых он является.

Будучи особой функцией человеческой психики, сознание индивида отражает значимые стороны окружающей действительности, целенаправленно анализирует, обобщает и оценивает все те стороны бытия, которые представляют наибольший интерес для данного индивида, на что было акцентировано его внимание, что его потрясло, разочаровало, обрадовало, вызвало чувство пессимизма или оптимизма и т.д.

В конечном счете, сознание человека способно адекватно отражать и осмысливать все грани той действительности, с которой человек сталкивается непосредственно или познает на основе информации, просвещения, образования. Сознание человека становится побудительной силой в плане преобразования окружающей действительности, борьбы со всем тем, что противостоит нормальному человеческому существованию.

Правовое сознание индивида является адекватной составной частью сознания как такового, но его сущность, содержание, назначение обусловлены спецификой права как общественного явления и его многообразными компонентами.

Известно, что правовое сознание индивида как субъекта права соотносится с правосознанием общества, иными формами его проявления. Но именно правосознание личности, каждого члена общества имеет первостепенное значение, оказывает решающее влияние на правовую действительность, а в порядке обратной связи отражает и фиксирует в себе все то, специфическое, значимое, решающее, что связано с правовой действительностью и с представлениями о ней с позиций правового идеала [2].

Правосознание личности формируется под влиянием права в целом, системы права, системы действующего законодательства, правовых идей, правовых принципов, правотворчества, правоприменительной практики, правосудия, правового образования, правового просветительства, правовой информации, юридической науки, правового воспитания, приобретенного юридического опыта и других правовых явлений и форм деятельности. Эти аккумулирую- 
щие правовое сознание правовые компоненты становятся все более тонкими, справедливыми, многогранными, перспективными, привлекательными, доступными в условиях развивающейся демократии, становления основ гражданского общества и правового государства, не только декларирования, но и реального обеспечения прав и свобод человека и гражданина.

Особое значение имеет уровень правосознания каждой конкретной личности и членов общества в целом. От этого в решающей степени зависят характер правового поведения субъектов права в соответствующих жизненных обстоятельствах, результаты правового упорядочения значимых общественных отношений и в конечном счете - возможности реализации тех или иных прав и свобод, представляющих интерес для членов общества.

При достаточно высоком, должном уровне правосознания той или иной личности можно констатировать наличие у нее исключительно позитивного правосознания, позволяющего ей мотивировать и осуществлять осознанное и предсказуемое правомерное поведение. Такое поведение обусловлено тем обстоятельством, что данный субъект права не только уважает действующую систему права, ее нормативноправовые акты и конкретные нормы права, но и обнаруживает в них те ценности права, которые являются основополагающими, приемлемыми и практически значимыми для его социальной и правовой жизнедеятельности.

При низком уровне правосознания конкретного индивида речь идет об определенной деформации содержания правовой идеологии и правовой психологии данного правосознания, о неготовности данного субъекта права осуществлять предсказуемое правомерное поведение в любых жизненных обстоятельствах. Это происходит в силу разных причин субъективного свойства (отсутствие правовых знаний, юридического опыта, навыков правового воспитания, игнорирование правовых предписаний в силу особенностей характера, надежда на удачный исход противоправных акций и др.). Но в любом случае низкий уровень правосознания объясняется отторжением тех ценностей права, которые могли бы изменить содержание правосознания соответствующего лица.

При позитивном правосознании личность принимает активное участие во многих сферах правовой жизни общества, целенаправленно инициирует необходимые поведенческие акции, направленные на достижение своих приоритетных жизненных интересов и потребностей. Все это осуществляется в фарватере правовых ценностей. Только личное, непосредственное участие человека в процессах регулирования общественных отношений, личное соприкосновение с позитивными и негативными сторонами правовой действительности, правовой анализ жизненных обстоятельств по горячим следам, акцентирование внимания на самых актуальных и злободневных сторонах правовой жизни общества становятся наиболее решающими компонентами развития содержания и уровня правосознания членов общества.

При деформированном правосознании соответствующий субъект права, как правило, осуществляет правомерное поведение, слепо копируя поведение других членов общества, примитивным, пассивным образом достигает реализации своих определенных жизненных интересов. Нередко, находясь в маргинальном положении, подобные субъекты права имеют склонность к совершению противоправных акций. Поиск ценностей в праве им противопоказан ввиду наличия таких элементов правосознания, которые не позволяют критически, со знанием дела оценивать правовые жизненные ситуации [См. напр.: 3].

При позитивном правосознании субъекты права анализируют и оценивают систему права с позиций ее целесообразности, рациональности, эффективности, справедливости, что и позволяет фильтровать те правовые ценности, которые призваны обусловливать социальный и правовой статус личности, претендующей на достойное существование.

Позитивное правосознание поддерживается и аккумулируется именно тем обстоятельством, что, несмотря на сложность, непредсказуемость жизненных обстоятельств, ценностные начала права пробивают себе дорогу, имеют перспективу проникать в систему действующего законодательства и тем самым обусловливать процессы реализации прав и свобод человека.

Своеобразный правовой оптимизм лежит в основе повышения уровня правосознания конкретной личности, инициирует ее на активизацию своих усилий в целях достижения желаемых жизненных результатов. Носитель позитивного правосознания имеет то преимущество, что предвидит, обнаруживает и вводит в практиче- 
ский оборот соответствующие ценности права, либо отстаивает необходимость их трансформации в систему права, в сферы реализации прав и свобод человека.

При деформированном правосознании, лишенном элементов правового оптимизма, индивид, образно говоря, течет по правовым жизненным обстоятельствам, не предпринимая правовой активности, акций критики, какого-либо интереса к окружающей правовой среде. Носители такого уровня правосознания в определенном смысле сами исключают себя из сферы поиска правовых ценностей.

Таким образом, правосознание при его достаточно высоком уровне не только выражает отношение субъекта права к правовой действительности, но и акцентирует его внимание на возможных (превентивных) позитивных нововведениях в правовой жизни общества.

Это дает возможность личности прогнозировать, моделировать, мотивировать свое правовое поведение в качестве правомерного в значительной степени потому, что в системе права он обнаруживает выгодные для себя ценности права и предполагает использовать их в своих интересах. В противном случае правомерное поведение осуществляется в основном из-за нежелания субъекта права иметь какие-то контакты с представителями государственной власти и из страха быть наказанным.

В конечном счете, правосознание (при любом состоянии его содержания и уровня) адекватно отражает все сущностные грани политической, экономической, социальной, нравственной и приоритетно правовой действительности. Благодаря своей многогранности, правосознание инициирует готовность его носителя участвовать в многочисленных, сложных, неоднозначных правовых метаморфозах, делать определенные выводы и на этой основе мотивировать свое поведение, деятельные акции, связанные с достижением тех или иных жизненных интересов и потребностей. При этом соответствующий субъект права как обнаруживает соответствующие правовые ценности, так и находится вне сферы их влияния, либо игнорирует, отторгает их.

Правосознание инициирует правовую активность личности не только на базе осмысленных ею правовых идей, концепций, взглядов, представлений, но и в унисон ее чувствам, эмоциям, переживаниям, надеждам и другим пси- хологическим качествам.

Позитивные состояния внутреннего мира личности, находящейся в правовом пространстве, в немалой степени связаны с обнаружением и восприятием определенных правовых ценностей. Отсутствие ценностей права в системе действующего законодательства обусловливает в целом неодобрительное отношение субъектов права к той социальной и правовой среде, где и протекает их основная жизнедеятельность.

Правосознание проявляет себя в любых юридически значимых общественных отношениях, в сферах правового поведения членов общества, во всех областях реализации юридических предписаний и требований. При этом личность как субъект права может обладать достаточно приличными правовыми знаниями, а может иметь лишь общее представление о действующих нормативно-правовых актах и юридических нормах, которые непосредственно влияют на ее жизненное положение, но воздействие позитивного или деформированного правосознания на соответствующее правовое поведение присутствует всегда. Правовое поведение - это конечный результат ознакомления, оценки, выводов относительно действующей системы права и ее отдельных компонентов.

Правосознание личности не просто вектор ее правового поведения, а многогранное функциональное явление, позволяющее любому участнику регламентируемых общественных отношений осуществлять поиск тех ценностей права, которые придают необходимое достоинство человеческому существованию.

Так, в рамках гносеологической функции позитивного правосознания накапливается тот информационный и образовательный набор правовых знаний (своеобразный мыслительный сгусток), который непосредственно указывает на уже обнаруженные и зафиксированные ценности права, в частности, те из них, которые подтверждают природу и провозглашают сущность естественных и неотчуждаемых прав и свобод человека.

Благодаря наличию оценочной функции правосознания, личность в качестве субъекта права стремится в обнаруженных ценностях права выявить те из них, которые в данных жизненных условиях могут наиболее эффективно содействовать успешному разрешению сложившейся правовой ситуации в пользу заинтересованной личности. 
Оценка всего позитивного и негативного в правовой жизни общества позволяет человеку занимать четкие правовые жизненные позиции и тем самым избегать нежелательных политических, социальных, юридических и иных последствий, деформирующих жизненный статус данного индивида. Именно оценочная функция в наибольшей степени подчеркивает наличие у данной личности именно позитивного, развитого правового сознания, позволяющего ей активно вторгаться в сложный и многообразный мир права.

Регулятивная функция правосознания непосредственно соприкасается с ведущими механизмами упорядочения общественных отношений, личностной необходимостью мотивировать и осуществлять определенное правовое поведение. При наличии позитивного правосознания, основанного на ценностях права, осуществля- ется, как правило, правомерное поведение, а при искажении, деформации правосознания определенных индивидов может иметь место их склонность к совершению противоправных поведенческих акций.

Таким образом, правосознание, как субъективное свойство человека, представляет собой отношение конкретного субъекта права к самому феномену права и его ценностям, оно фиксирует реакцию на систему права и ее отдельные компоненты, подчас интуитивную, подсознательную [1, с. 265]. Позитивное правосознание значительной части членов гражданского общества становится мощной движущей силой развития действующей системы права, внедрения правовых законов, успешной реализации естественных и неотчуждаемых прав и свобод человека.

\section{Библиографический список}

1. Алексеев С. С. Право. Опыт комплексного исследования.-М., 1999.

2. Токарь Н.С. Правовое сознание личности в контексте формирования гражданского общества в России. Дисс. на соиск. уч. степени канд. философ. наук. Краснодар, 2006.

3. Аминова Ю.А., Кожевников В.В. О правовом невежестве и других формах деформированного правосознания // Вестник Омского университета. Омск. № 3. 2014. Сс. 30-35. 